tion of the individual grains as separate particles, because the contact of one grain with another would prevent such vibrations, and suggested that the only other explanation possible was that certain grains, in rubbing one against another, might produce the required vibrations through surface friction.

The music from sands is a cumulative effect, and only possible under the prevalence of numerous favourable conditions, and I found that if I eliminated one apparently insignificant factor from the conditions upon which my theory was based, the production of musical sands artificially became impossible.

Until an artificial musical sand can be produced exclusively under the conditions suggested by Profs. Poynting and Thomson in "Sound," I submit that my explanation may be retained.

Cecil Carus-Wilson.

\section{Filtration of Rain Water.}

I wIsH to ask the opinion of someone in regard to the filtration of rain water, and the removal of any sediment, before it finds its way into large underground cisterns holding fully 15,000 gallons.

It will not be difficult or costly to collect the water and pump it up for use in a large laundry. A pump can be worked by the engine close by.

The point is how to prevent a lot of smuts, \&c., finding their way into the cisterns, which would necessitate the frequent removal of this stuff, an operation that would be both difficult and expensive.

Is there any way by which filtration can be carried out above ground?

I shall be glad to know of any way to meet the difficulty. January 13 . ENQUIRER.

\section{THE HIGHLAND OVERTHRUSTS. ${ }^{1}$}

THE controversy regarding the structure of the north-western Highlands was a disturbing factor in the progress of geology from I8I9, when the problem was first raised by Macculloch, until it was closed in 1884 by Sir Archibald Geikie's announcement in Nature (vol. xxxi., p. 29) that the generally accepted view could no longer be maintained. The NATURE article-perhaps the most sensational announcement in geological literature-was followed in I888 by a report from six members of the Scottish Geological Survey (Messrs. Peach, Horne, Gunn, Clough, Hinxman, and Cadell), giving a summary of the evidence which they had collected as to the structure of the north-western Highlands; and it has taken another twenty years to complete the survey of the whole overthrust region and prepare the detailed observations for publication. The full results are now issued in an elaborate monograph, the most important and the cheapest publication ever issued by the British Geological Survey. It includes 700 crowded pages, 52 artistic and instructive plates, and a beautiful colour-printed geological map of the whole area on the scale of four miles to the inch. The price of the book is ros. $6 d$. The Survey is to be congratulated on having secured for this memoir a style of production far superior to the usual standard, and on its issue at a price which should ensure for it a wide circulation.

The book no doubt suffers from the inevitable compromise between conflicting requirements. Many readers will never have the opportunity of visiting north-western Scotland, and they will seek in this volume for a clear statement of the general results; their needs are satisfied by the fine photographic plates of the scenery, which show the overthrust

1 Memoirs of the Geological Survey of Great Britain. The Geological Structure of the North-west Highlands of Scotland. By B. N Peach, John Structure of the North-west Highlands of Scotland. By B. N Peach, John
Horne, the late W. Gunn, C. T. Clough and L. Hinxman, with Petrological Horne, the late W. Gunn, C. T. Clough and L. Hinxman, with Petrological
Chapters and Notes by J. J. H. Teall. F,ited by Sir A. Feikie. Pp. xviii +668 ; plates lii., map. (Glasgow: H.M. Stationery Office, rgo7.) Price ros. $6 d$.

$$
\text { NO. } 1995 \text {, VOL. } 77\rceil
$$

structures more clearly than they are often visible through the persistent mists of the west Highland hills, and by the masterly introductory statements by Dr. Horne in chapters i., iii., xxxii., and xl. (of the last of which Dr. Teall is joint author), and the corresponding chapters by Hinxman on the Torridonian, and by Horne and Peach on the Cambrian. The memoir has also to serve as a field handbook to those who can visit the district. Accordingly it has to give precise information, which cannot be too detailed, as to localities and sections. The bulk of the book consists of detailed local descriptions, written by Messrs. Peach, Horne, Clough, Hinxman, and the late W. Gunn, with notes by Cadell, Greenly, and Harker. A third group of geologists will turn to the volume for help in the investigation of other regions of crystalline schists, for nowhere has so large and comprehensive an area of these rocks been subjected to such a searching investigation. The conclusions of this work and the most important evidence are given in a detailed account by Dr. Teall of the gneisses, and altered sedimentary rocks associated with them. The appendix includes a list of fossils and fossiliferous localities, a chemical study of the Durness Dolomites by Dr. Pollard, and a full bibliography by Mr. D. Tait.

The book therefore combines chapters which can be read with advantage by any geological student and others which have to be judged as a collection of materials for reference by specialists. The memoir is appropriately edited by Sir Archibald Geikie, who started the work in 1883 , and carefully supervised its progress for eighteen years, until his retirement from the Survey in Igor. It is doubtless due to his literary skill and sense of proportion that the book enjoys a greater uniformity in style and treatment than would be expected in a work extending over so many years, and written by so many men.

The history of the north-west Highlands controversy is summarised in a chapter by Dr. Horne, who lucidly states the results of all previously published geological work on the district. The geological interest of the area dates from the announcement by Macculloch, in 1819 , of his discovery of fossiliferous rocks lying above gneisses, and covered by the gneisses and schists that form the great bulk of the Scottish Highlands. Murchison, with his keen scent for a good clue, visited the area, and he re-examined it after the discovery by $\mathrm{C}$. Peach, in 1854, of the better fossils (now known to bə Cambrian) in the Durness limestones. Murchison was convinced that the fossiliferous rocks were covered by the eastern gneisses, and, in accordance with the law of superposition, accepted the eastern gneisses as younger than the rocks beneath them. He regarded the fossils as Lower Silurian, and therefore did not shrink from the apparently inevitable corollary that most of the crystalline rocks of the Scottish Highlands are post-Lower Silurian in age. This conclusion had a world-wide influence. Similar crystalline schists form vast regions in all the continents, and they were at first regarded as all pre-Palæozoic; but if the Scottish schists are altered Palæozoic sediments, then the similar rocks elsewhere may include rocks of any geological age. To this day vast regions of schists and gneisses are mapped as altered Silurian, in consequence of Murchison's work on the north-west Highlands.

Murchison's views were at once opposed. The common-sense judgment of James Nicol showed him the improbability of Murchison's conclusions, and his keen and careful field-work revealed that the superimposing of schists over sediments was not an original arrangement, but was due to subsequent earth movements. The first controversy was short. Nicol's inter- 
pretation of the evidence had not the fascinating simplicity of the other theory, and it was not wholly right. The eastern and western gneisses are not simply repetitions of the same series, and Murchison was apparently right in his view that the upper gneisses and schists are an independent and younger series than the Lewisian gneisses, which underlie the Cambrian band to the west. Moreover, Nicol failed to realise that the apparent bedding planes in the eastern gneisses were not original, but secondary structures due to earth movements.

Murchison, with a theory attractive by its charming simplicity and far-reaching results, and right in his recognition of the essential differences between the eastern and western gneisses, swept his critic from the field. Nicol, disheartened by the fate of views
Nicol's researches"' (p. 23), was not enough, although it was supported by the work of Callaway and Hudleston. In I882-3 Prof. Lapworth mapped in detail the classic sections on the shores of Loch Eriboll; he proved that the apparent sequence was deceptive, and that the eastern gneisses were older than the fossiliferous rocks, and had been placed above them by earth movements; and it was his crowning glory to recognise that many of the finegrained, shale-like rocks, which look like comparatively unaltered sediments, are the most intensely altered rocks of the area; they consist, like ordinary shales, of fragments of primary rocks, but instead of having been formed by the usual agents of denudation and deposition, they are due to crushing along planes of earth movement.

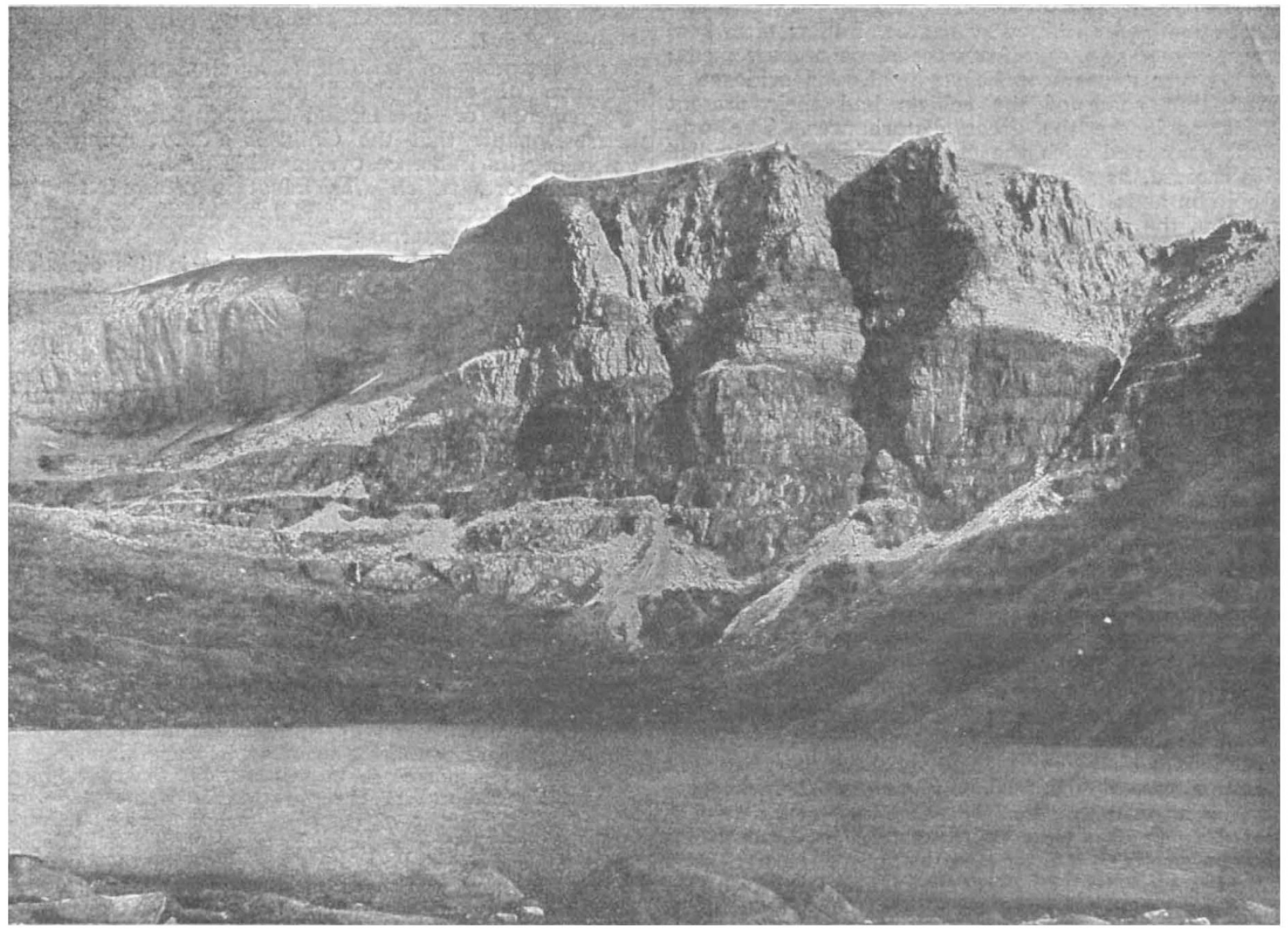

Unconformability of Cambrian quartzites on Tcrridon sandstone. Loch Coire Mhic Flearcha' $r$, B $\epsilon$ inn Eighe, Ross-shire. Reproduced $x$ ith the atthority of the Controller of H. M. Stationery Office.

which he knew to be essentially correct, practically gave up geological research, and went to his grave, his geology despised and his conclusions rejected-by all except his wife. In 1878 , the year before Nicol's death, the controversy was re-opened by that geom logical knight-errant, Dr. Hicks, who ran a tilt against the Murchisonian theory. It survived his onslaught, but two years later it received an almost fatal blow from Prof. Bonney, who, by work near Loch Maree, demonstrated that some of the rocks of the eastern series were the old Lewisian gneiss brought up by faults. The establishment of this fact, which is described in the memoir as "the first important advance towards the solution of the problem of the succession in the north-west Highlands since the publication of
The close of the controversy was now near at hand. In I883 Sir Archibald Geikie arranged for the detailed mapping of the Loch Eriboll district by the Geological Survey. The work was soon found to be far more complex than had been expected; it was attacked with invincible patience and thoroughness by the surveyors under Peach and Horne; the essential conclusions of Nicol and Lapworth were confirmed, and it was promptly announced in NATURE that the Murchisonian theory must be abandoned. In I888 a preliminary report on the Survey's investigations was published by the Geological Society, but it has taken another nineteen years to extend the survey along the whole of the overthrust line, and to prepare the materials for publication. 
The work is of the highest geological importance, and in spite of its necessary descriptive details, every page contains observations of interest. The account of the Torridonian series, for example, describes the oldest considerable land surface known, and some traces of fossils in these pre-Cambrian rocks. The part of most interest is the account of the movements by which the eastern gneisses have been overthrust on to the younger rocks. The movements have taken place along a line more than roo miles in length, and have carried the rocks in places for ten miles westward. The thrusting forward of these hard rock slices has produced a most intricate system of faults, and extreme changes in the rocks, some of the fresh structures, as in the pseudo-rhyolites, simulating those of igneous rocks. The extent of the metamorphism is one of the secondary questions of most interest. Its range appears to be very variable; in places the alteration is confined within very narrow limits; elsewhere it may extend to a mile from the plane of movement; but it never appears to be regional, and evidence is given that some of the schists had their present structures before the great disturbances. The problems connected with the eastern schists are handled with reserve, as there seem to be marked differences of opinion as to their age and origin; but on the main question, the relation of the schists to the fossiliferous rocks, the memoir, with its convincing combination of fulness of detail and clearness of exposition, leaves no room for doubt.

\section{J. W. GreGory.}

\section{THE TOTAL SOLAR ECLIPSE OF JANUARY 3, Igo8.}

THE first cablegram, containing news relating to the eclipse of January 3 , observed by the parties stationed on Flint Island in the South Pacific, reached this country on Saturday last. The cable was from Mr. F. K. McClean, and was dispatched immediately on his arrival at Auckland, New Zealand. It read as follows :- " Partial success, fine morning, heavy rain several minutes until totality; first minute cloudy, remainder clear. Four corona results; none spectrum; bad plates; other observers not developed. Campbell reports success."

The above news is really very satisfactory, because it was anticipated by those at home that the weather conditions which generally prevailed at that time of the year would most probably prevent any observations at all being made. There is, however, no doubt that the parties were very fortunate, since, according to the above account, the clouds only just cleared from the neighbourhood of the sun in time.

Those who have been on like expeditions will be able to picture to themselves the anxiety which must have prevalled among the observers as totality was approaching. The heavy rain must have necessitated the covering up of all the instruments, more especially the silvered mirrors and object glasses. The clearing up, after totality had begun, must have created a condition of affairs which was probably not legislated for in the "rehearsals" which had no doubt been daily gone through.

The fact that the length of totality was of four minutes' duration gave probably sufficient time for all the instruments to be brought into use. It is hoped, therefore, that a very complete record has been obtained of the latter portion of totality, and, if this be so, then the term "partial success" may be changed to complete success.

With regard to actual results obtained little is known at present. The reason of this is that the development of the negatives secured was not com- pleted on the island. Mr. McClean provided himself with a dark room on board the steamer he had chartered, so he may have developed his corona negatives on his way back to Auckland. According to his cable four of the plates he exposed were successful, but the words "bad plates" seem to suggest that the results he obtained were not so good as they might have been.

Reuter reports that the observations of the different parties at Flint Island and Samoa were, generally speaking, fairly successful, and mentions specially that the bolometric measurements of the heat of the corona made at Samoa were successfully made. William J. S. Lockyez.

\section{THE BRITISH SCIENCE GUILD.}

THE second annual meeting of the British Science Guild was held on January I5 at the Mansion House, the Lord Mayor being in the chair. The large assembly of fellows and members, and the presence of distinguished representatives of many departments of intellectual activity and national interest, show that the Guild is strengthening and extending its influence over a wide field.

'The report, which was adopted, referred to the missionary work of the Guild in educating the public in the following terms:-

The executive committee believes that in this direction the labours of the Guild are becoming more effective each year, and there is a gradually increasing volume of opinion chronicled or expressed in the daily and weekly Press in harmony with the main objects of the Guild.

For this result a large debt of gratitude is due to the president, Mr. Haldane, who has taken many opportunities of expressing and emphasising the views of the Guild tefore large audiences in connection with various educational institutions.

It is in the direction of primary education that the most rapid advance in public opinion has taken place, and on this the nation is to be congratulated, for it is on the proper education of the children that all future progress must ultimately depend. At the inaugural meeting of the Guild in 1905, the chairman of committees, in referring to the subject of education, pointed out that a complete education must be based upon things and thinking as well as words and memory, and that we want "one kind of education for everybody-the Best." Further, that no one should be stopped on his upward course save by his own incapacity; and that all impediments should be removed. These views are now being acted on in many places.

The Guild is not alone in pointing out that our great commercial competitors are those lands where there is the greatest number of complete and State-aided universities, and in which as a consequence "all the national activities are carried on in the full light of modern science by men who have received a complete training both in science and the humanities, in close touch with the Governments."

Some of the City livery companies have shown great interest in the work of the Guild. The Clothworkers' Company has made a donation of rool. to the funds, and the Drapers' Company one of rosl. This evidence of the interest taken in the movement is very gratifying, and it is hoped that other City companies will similarly assist in furthering the objects of the Guild.

Numerous subjects have occupied the attention of the executive committee during the year, and several deputations to various Ministers of State have been arranged. Among questions thus dealt with may be mentioned the amendment of patent laws, the anthropometric survey of school children and adults, and the prevention of pollution of rivers. Deputations had also been planned to the Colonial Premiers and in connection with vivisection licences, but subsequent circumstances made these unnecessary. 